New Zealand journal of industrial relations, 1990, 15, 219-240

\title{
The floor of rights in European labour law
}

\author{
Simon Deakin*
}

Most European countries have legislated to provide a basic floor of rights which underpins collective bargaining. This article reviews the experiences of the major European countries and examines the way that the floor of rights is being extended. It also discusses the floor of rights in the context of the search for labour market flexibility.

\section{Introduction}

The concept of the floor of rights within labour law has a specific meaning: namely, the provision by legislation of minimum standards for the contract of employment, as a "floor" or base upon which collective bargaining is meant to build (Wedderburn, 1986). The content of the floor of rights consists, first of all, of laws laying down certain basic terms and conditions: in particular, maximum working hours, minimum wages and health and safety standards. Secondly, there are laws concerning the suspension and termination of the contract of employment itself: laws governing sickness and lay-off, the regular payment of wages, unjust or "unfair" dismissal, redundancy and also unemployment benefits. Thirdly, the law may provide specific or additional protections for certain groups of workers, with the aim of eliminating socially undesirable discrimination: in this category we may classify laws protecting union members and officials from dismissal, protecting pregnant workers and outlawing discrimination based upon, amongst other things, sex, race, nationality or disability.

At the Strasbourg summit of 8-9 December 1989, a declaration of the basic social and employment rights of workers was adopted by 11 out of the 12 member states of the European Community (EC). This new "Social Charter" - more properly known as the Community Charter of the Fundamental Social Rights of Workers - represents a commitment in broad terms to the achievement of basic social standards within the single European market after 1992. The commitment to a legal floor of rights to terms and conditions of employment is characteristic of the development of European labour law since 1945. Notwithstanding the impact of 10 years of so of policies of deregulation and "flexibilisation" in the area of labour and social law, 2 features above all distinguish the national systems of western Europe: the use of the law to entrench a high level of minimum standards in the employment relationship; and the continuing role of collective bargaining as a mechanism for building on these legal minimum rights, a role which in many ways has become more and not less important with the need to introduce a greater degree of flexibility into the form and application of legal standards.

Arguments for deregulation or de-legalisation have not gone unheeded within the Community, and there is a general recognition of the need to adopt measures which will assist in the reduction of unemployment or will, at least, avoid the imposition of excessive employment costs upon employers, in particular smaller firms. These arguments have been advanced furthest as a basis for policy in the United Kingdom,

* Faculty of Law, University of Cambridge. The author would like to thank Mark Minford for his advice and for his permission to reproduce the figures contained in Table 2. 
which declined to join the other Community states in endorsing the Social Charter and continues to resist, as far as possible, the goal of a general harmonisation of social rights within the single market. The British Government argues that the most effective form of "social progress" is the growth in jobs and economic opportunities which it ascribes to the policy of deregulation. This can hardly be reconciled to the principles contained in the new Charter or, for that matter, to general principles of international labour law.

However, it is possible that without effective implementation of high social standards throughout the Community, a form of "creeping deregulation" will take place once national barriers to the movement of labour and capital are removed and a "transparent" single market puts pressure on states to attract capital and resources by cutting employers' fiscal and legal costs. Under these conditions, "firms are able to escape, or threaten to escape, statutory or collectively agreed social protection by relocating their operations within the increasingly Europeanised economy" (Mosley, 1990). To counter this trend there is a powerful argument in terms of both equity and efficiency for the entrenchment of social and labour standards at a high level within the single market (Mückenberger and Deakin, 1989).

\section{The social dimension to the European single market}

Social policy did not feature highly among the original aims of the founders of the EC (Hepple, 1987). The 1957 Treaty of Rome made provision for the adoption of Community Directives (which are in effect instructions to member states to introduce national legislation on particular matters) and Regulations (which are directly applicable in national law) in the area of social policy as part of the general aim of implementing the common market, and made reference to the desirability of social harmonisation and the upwards improvement of social standards. Until the early 1970 s, however, there was no systematic programme of social harmonisation at Community level. In part, this was because of a view which held that the gradual implementation of the "common market" would see a convergence in social standards around the best features of the various national systems without the need for specific legislative direction from the centre.

This situation changed in the $1970 \mathrm{~s}$ as a result of 2 parallel developments. The first was the adoption of a Social Action Programme to coincide with the expansion of the Community beyond the original 6 members in the early 1970s. This led to agreement by the member states on a number of Directives in the field of social and employment law, ${ }^{1}$ concerned on the one hand with protection the position of employees affected by economic restructuring (as in the case of the Directives on Collective Redundancies (1975), Acquired Rights on Company Transfers (1977) and Employer Insolvency (1980)) and on the other with the achievement of equal treatment for women in employment and social security (most notably the Directives of 1975 on Equal Pay, 1976 on Equal Treatment in Employment, 1979 on Equal Treatment in Social Security and 1986 on Equal Treatment in Occupational Social Security).

The second parallel development was the application by the European Court of Justice of the legal doctrine of "direct effect" to certain of the social law provisions of the Treaty of Rome and to the Directives of the 1970 s, as a means of granting individuals rights which were enforceable in national courts even in the absence of effective domestic

1 Under the constitutional rules of the European Community, Directives and Regulations are prepared and formulated by the European Commission, which is the bureaucratic and administrative arm of the Community, sometimes in consultation with the European Parliament. These measures are then put to a vote of representatives of the member states sitting in the European Council. 
legislation. ${ }^{2}$ The assertion of the supremacy of Community law in the area of equal treatment has had widespread repercussions in national law systems for equality of pay, equal employment rights and the treatment of female part time workers. This process is still continuing today.

For most of the $1980 \mathrm{~s}$, however, progress on the legislative front was held up at least formally by the opposition of the Thatcher administration in Britain to new initiatives for Directives in the social field. Under the constitutional arrangements in force during this period, the adoption of such Directives required the unanimous support of the national governments, so giving the Thatcher government an effective veto over these proposals.

The Single European Act of 1986 made a series of amendments to the Treaty of Rome which aimed to speed up the process of economic integration by making greater provision for majority voting on proposals for Community-wide legislation. At the same time the European Commission, which is responsible amongst other things for the preparation of Community legislation, launched a programme of institutional reforms designed to achieve a "single market" by the end of 1992. The aim of a "European social area" was part of this programme. However, while the Single European Act introduced the possibility of "qualified majority" voting over a wide range of issues designed to implement the 1992 project, it also made a number of exceptions, most notably in the areas of taxation, the free movement of persons and the rights of employees. The one area of social policy where qualified majority voting was clearly permitted was the area of the "working environment" and specifically occupational health and safety. Accordingly, in June 1989 the national governments gave their approval to a range of Directives concerning health and safety which seek to generalise some of the best elements of national practice (Eberlie, 1990).

The adoption of the Social Charter did not create any new legally-binding obligations upon member states as it is only a "solemn declaration of fundamental social rights at Community level". It remained for the Commission to propose, in its Action Programme of November 1989, a series of new Directives which will implement the general principles of the Charter. Together the Charter and the Action Programme represent a significant commitment to the generalisation of social standards in the areas of both individual and collective labour law rights. There are general references in the Charter to the need to ensure minimum levels of working and living conditions, fair remuneration, social protection, equality of treatment and special protections for vulnerable groups in the labour market (the young, the old and the disabled). The maintenance of health and safety, the provision of adequate training and freedom of movement are matters which receive more specific attention. At the collective level there are references to freedom of association and to the right to strike, although there is a great deal of doubt about the precise terms of these provisions. ${ }^{3}$

The Commission's Action Programme contains a number of more specific proposals for legislation. However the draft Directives and Regulations still require the approval of the member states before they are to become legally operative. In some areas it is clear that a qualified majority in the European Council - which consists of the representatives

2 Regulations are "directly applicable" in national law, which means that they may be applied without the need for additional national legislation. Directives, on the other hand, presuppose some kind of implementing measure by the member states. This distinction has however been blurred by the doctrine of "direct effect", under which certain rights contained in Directives may be applied against national governments even if they have failed to introduce the necessary legislation. Certain rights contained in the Treaty of Rome itself - such as the right to equal pay contained in Article 119 - are directly effective between private citizens and so may affect the employment relationship itself. See Wyatt (1989).

3 See Wedderbum (1990) for a fuller account of the Treaty and Action Programme. 
of the national governments - will suffice. This was the case for the health and safety Directives of 1989 , although in the result there were no dissenters.

The Commission has recently put forward draft Directives in the areas of atypical employment and working time, and here the legal position is more unclear (VogelPolsky, 1990). The issue is important as the British government will exercise its veto to block these proposals unless they can be voted through on a qualified majority which would override British opposition. There are 3 proposed Directives on atypical employment which seek, in general terms, to ensure parity of treatment of part time and temporary workers with full time employees. One of them will require unanimity from the member states as it is put forward under powers which pre-date the Single European Act, while another is concerned with occupational health and safety and so may in principle may be voted through on a qualified majority as explained above. The third and most controversial proposal has been put forward under the general power to use qualified majority voting to implement the single market, even though it would appear to relate to the the rights of employees and so should require unanimity. However, the Commission has argued that the existence of different regulations concerning atypical work in the member states creates potential distortions of competition, and that this, rather than the protection of employees' rights as such, is the basis for the proposed harmonisation. The draft Directive on working time has been put forward under the heading of occupational health and safety on the assumption that it will only require a qualified majority. There is some doubt as to whether this issue can legitimately considered as a health and safety question.

The prospects for a more complete implementation of the Action Programme depend to a large degree on the Commission's success with these early proposals, and this no doubt accounts for the cautious approach which the Commission has adopted up until now. The Commission needs to obtain general support among the member states for a programme of legislative reform and there is already concern that vital issues have been watered down, or deferred, in order to gain such a consensus. The draft Directives on atypical work, for example, appear to be much less rigorous than earlier attempts to propose Community-wide legislation in this area, and any early progress on general standards for the minimum wage has been ruled out. None of this, however, precludes more extensive harmonisation at a later stage.

\section{Minimum statutory employment standards in national legislation}

\section{Hours and wages}

Controls over the length of the working week were among the first to be established on a comprehensive basis in western Europe, after the first World War (Vogel-Polsky, 1986; Blanpain, 1988). In France, legislation established the 8 hour working day in 1919 and a 40 hour week in 1936. This legislation was re-established in 1946. Further legislation in 1982 established a basic norm of 39 hours per week, but with provisions for flexibility to be achieved through plant-level collective bargaining (this is discussed further below). Overtime is also regulated: weekly hours must not exceed 48 in total, or an average of 46 per week over a 12 week cycle. These limits can be exceeded only with the authorisation of the labour inspectorate.

In West Germany the basic law governing working time dates back to 1938, when an 8 hour day and 48 hour week were established. This has since been lowered by collective bargaining, so that a 40 hour standard was nearly universal by the late 1970 s. Since then there have been further reductions in basic hours in particular in the engineering industry, which established a general 38.5 hour working week by agreement in 1984. A further 
agreement in the engineering sector in 1987 made provision for a reduction in the basic working week to an average of 37.5 hours by April 1988 and 37 hours by April 1989. In law, overtime is permitted up to 2 hours per day and 10 hours on 30 days in any one year; for this purpose however the benchmark is the 48 hour week which remains the legislative standard. In practice collective bargaining regulates overtime above the current conventional limits.

Table 1: Working time regulations in the European Community, 1987

\begin{tabular}{|c|c|c|c|c|c|c|}
\hline \multirow[b]{2}{*}{ Country } & \multicolumn{2}{|c|}{$\begin{array}{l}\text { Working week } \\
\text { (hours) }\end{array}$} & \multicolumn{2}{|c|}{$\begin{array}{l}\text { Actual hours worked } \\
\text { (full-time employees } \\
\text { average weekly hours } \\
\text { including overtime) }\end{array}$} & \multicolumn{2}{|c|}{ Annual leave } \\
\hline & By law & By agreement & Male & Female & By law & By agreement \\
\hline Belgium & 40 & 37 to 40 & 39.2 & 38.3 & 4 weeks & 4-5 weeks \\
\hline Denmark & 39 & 37.5 to 40 & 39.1 & 37.0 & - & 5 weeks \\
\hline France & 39 & 35 to 39 & 40.9 & 38.6 & 5 weeks & 5-6 weeks \\
\hline Greece & 41 & 35 to 40 & 39.7 & 37.7 & 4 weeks & As by law \\
\hline Ireland & 48 & 35 to 40 & 42.0 & 38.6 & 3 weeks & 4 weeks \\
\hline Italy & 48 & 36 to 40 & 39.6 & 36.4 & - & 4-6 weeks \\
\hline Luxembourg & 40 & 37 to 40 & 40.3 & 38.4 & 5 weeks & 25-29 days \\
\hline Netherlands & 48 & 36 to 40 & 40.9 & 38.6 & 3 weeks & 4-5 weeks \\
\hline Portugal & 48 & 34 to 48 & 42.0 & 39.0 & 30 civil days & s $4.5-5$ weeks \\
\hline Spain & 40 & 37 to 40 & $39.2^{\mathrm{a}}$ & $36.3^{\mathrm{a}}$ & 30 civil days & s $4.5-5$ weeks \\
\hline West Germany & 48 & 37.5 to 40 & 41.7 & 40.4 & 3 weeks & 5.5-6 weeks \\
\hline United Kingdom & $1-$ & 35 to 40 & 42.4 & 37.2 & - & 4-6 weeks \\
\hline
\end{tabular}

Source: Trade Union Congress (1988).

Notes: a Spanish figures include part time work.

This pattern is repeated in a number of other European countries, in which legislative standards have been outstripped by sector-level collective agreements (see Table 1). In Denmark, there is no statutory regulation but sector-level agreements backed by law set a 39 hour week for blue collar workers and an average 37.5-38 hour week for white collar workers. Other countries setting a shorter working week for white collar workers are Sweden, the Netherlands and Britain. Legislation and collective agreements in most European countries also regulate shift working, nightwork and weekend breaks. Sunday 
work is strictly regulated in most countries and there are specific constraints upon nightwork in blue collar occupations by women and young workers. In a number of systems these restrictions may be modified by plant-level collective bargaining (see below).

The provision of paid holidays is governed by legislation in nearly all countries. In France, Spain, Sweden and Denmark, for example, legislation sets a high standard of 5 weeks' paid leave per year. In Germany, on the other hand, legislation of 1953 sets only 3 weeks' annual paid leave and improvements since then have been brought about by collective bargaining, which has established up to 6 weeks or 30 days paid leave in the engineering and chemical sectors. In Italy there is no legislative provision beyond the broad terms of Article 36 of the national Constitution, but collective agreements set a general standard of 4 weeks' paid leave for all employees after one year of service. In most countries these provisions for paid annual holidays are in addition to legislation and agreements which set aside certain days as paid public holidays.

Legislation and, in some systems, collective agreements regulate in more detail the calculation of holiday pay and bonuses. In West Germany, for example, most collective agreements provide for employees to receive holiday bonuses over and above the basic rate of pay for the days of holiday and an annual bonus, so creating an extra salary for the "thirteenth month" (European industrial relations review, 1987).

The major exception to the pattern of statutory regulation of the basic working week is Britain, where there are no general legislative standards on the duration of the working week and no legislation on either public holidays or paid annual leave. The last remaining selective hours regulations, dating from the 1930 s, which set a basic 48 hour week for women and young workers in factory employment, were repealed in 1986 and 1989 as part of the policy of deregulation (Deakin, 1990). In low paying trades with statutory wages councils, whose orders are legally binding, a 39 hour week is generally recognised.

In the absence of legislation, sector level collective agreements in Britain have achieved a general lowering of daily and weekly hours since the 1920 s when a basic 6 day week of 48 hours was first established in the engineering sector. The basic week for manual workers in the engineering sector was gradually reduced from 44 hours immediately after World War Two to 39 hours and a 5 day week in the early 1980s. This standard was generally adopted in all sectors during the 1980 s. White-collar workers have traditionally enjoyed a shorter working week than the manual grades covered in national agreements; a 37.5 hour week is now the general norm for them.

Even if sector-level agreements in Britain have performed some of the functions of legislation in other countries, a principal substantive difference between Britain and other western European systems is the extent of overtime working. British collective agreements do not, on the whole, seek to limit actual overtime hours; they are confined to setting overtime premium rates. This is one reason why overtime working in manufacturing is far more extensive in Britain than elsewhere in Europe. There is also a considerable degree of variation across sectors in the length of the working week in Britain once overtime is taken into account, with employees in some sectors working very long weekly hours (Rubery et al., 1990).

Holiday entitlements in Britain are also regulated by sector-level collective agreements, with a gradual trend during the 1980 s building on the 4 weeks standard. Around one fifth of blue collar employees are now covered by agreements providing for 5 weeks' paid holidays; for white collar employees, 4 to 5 weeks is the norm with the possibility of service-related increments to this basic entitlement (Rubery et al., 1990).

All systems have some form of minimum wage regulation, but they differ in the type of legal mechanisms used, in terms of the workers covered and in the level of the minimum in relation to average prices and wages (Minford, 1989). In France the statutory minimum wage or SMIC (salaire minimum interprofessionel de croissance) is index-linked to both price and wage increases. This specific linkage was the purpose 
behind the introduction of the SMIC in 1970, replacing an earlier law of 1950 . Every 2 percent rise in the consumer price index triggers a rise in the minimum wage, in addition to which there is provision for a yearly review which must ensure that the annual growth of the minimum wage is not less than 50 percent of the growth in the purchasing power of the average wage. Other countries with a statutory minimum are the Netherlands, Luxembourg, Spain and Portugal. In the Netherlands there is provision for twice yearly wage increases to keep the statutory minimum in line with the index of wages, although the normal procedures were frozen in 1983 and some cuts in the statutory minimum were imposed after that. In Portugal there are annual government reviews but there is no legal guarantee of index linking nor of any automatic yearly increase. The annual review uses forecasts of future price and wage rises rather than historical wage growth, and this can result in under-estimates of the effect of price inflation. In Spain, yearly increases are again based on the projected rate of price inflation, but there is provision for further increases at 6 month intervals if the official estimate proves to be too low.

A number of systems seek to achieve comprehensive coverage through the collective bargaining system. In Belgium, a national level collective agreement is concluded annually by representatives of trade unions and employers' associations, as part of which the minimum wage is linked to rises in the consumer prices index. The national minimum only applies in the absence of an industry-level collective agreement for the work in question, and in practice most sectors are covered by such agreements. National level collective bargaining on the minimum wage, supported by the force of law, also operates in Greece.

In West Germany and Denmark, by contrast, basic minima are supplied by sectorlevel collective agreements, whose terms are generally binding in law (see below). It is estimated that approximately 90 percent of the West German labour force is covered by industry-wide agreements, which set wage rates which are the subject of annual renegotiations. Legislative provisions exist for the extension of minimum terms and conditions of employment to non-union firms, and for the application of minimum rates in collective agreements to sectors where effective bargaining does not exist. In Denmark there is a dual minimum wage system, with some sectors operating a low "minimum wage" which sets a base for bargaining over additional rates at company level, and others operating a more effective sector-level minimum known as the "standard" wage. Collective agreements cover between 80 and 85 percent of the workforce. There has been no automatic indexation since 1983 and from 1985-86 government measures have imposed limits on annual wage increases.

A similar effect operates in Italy as the result of an activist judicial interpretation of Article 36 of the national Constitution which guarantees each worker the right to a "fair wage" in proportion to his or her own work and to their family's consumption needs. Agreements for lower wages are void and the courts will apply instead the minimum wage derived from the relevant national collective agreement. However, the coverage of this system is limited within the extensive small firm sector and the legal remedies available are not as effective as the "extension" legislation which operates in France and Germany, as it is up to the individual to bring any claim. As a result there has been a considerable debate within recent years about the merits of introducing a more comprehensive statutory minimum wage. In addition to the minimum contractual pay laid down by collective agreements, automatic cost-of-living increases take effect annually through the scala mobile which has statutory force.

At the other extreme of minimum wage regulation are the British and Irish systems, where statutory regulation of minimum pay and conditions is confined to certain lowpaying trades. Regulation takes the form of tripartite bodies which are in effect statutory substitutes for collective bargaining - in Britain the Wages Councils, covering about 2.5 million workers or 9 percent of the employed labour force, and in Ireland the Joint Labour Committees which cover 30,000 workers or about 2 percent of the workforce. Terms and conditions in wages orders are legally binding on all employers within the scope of the 
relevant sector, but there is no legal requirement for these minimum wage rates to keep pace with average prices or with wages. In Britain the Wages Act 1986 limited Wages Councils to setting single pay rates for each sector, and made a number of other changes which have limited the impact of this form of regulation (see below). National level agreements outside the statutory sectors also play an important role in setting minimum wage rates, but in the common law systems these collective agreements do not have an automatic legal effect and so will not normally be binding on non-union firms. Furthermore, unlike in West Germany or Denmark where the coverage of sector level bargaining is comprehensive, there are significant sectors in Britain without effective national level bargaining, such as retail and distribution and large parts of private services.

The rates at which minimum wages are set in relation to average wages vary greatly, as do the rates between different countries even within the EC. Table 2 gives indications of the minimum wage in each of the EC countries, calculated as a percentage of the average wage in each system. The figures range from around 70 percent and over in France, Greece, West Germany, Denmark and Portugal, to 50 percent or less in Ireland, Spain and the United Kingdom. Another comparative indicator is the conversion of the minimum rates into $£$ sterling at the purchasing power parity exchange rate which makes it possible to compare the consumption level provided by the minimum wages. According to calculations carried out by Mark Minford for the Low Pay Unit in 1989, the minimum rate set by the Wages Councils in the UK is barely half that set by collective agreements in West Germany, and more on a level with those of Greece, Spain and Portugal (Table 2).

Numbers directly dependent upon the minimum wage also vary between countries, and within countries there are variations according to sector and firm size. Employees in smaller firms and in non-industrial sectors tend to be more heavily dependent on the minimum wage as an absolute floor to wages. France has one of the smaller percentages of workers who receive pay which is at the level of the minimum wage - in 1985 this was estimated to be 7.3 percent of employees in firms with 10 workers or more, and 16 percent of those in smaller companies (European industrial relations review, 1986). In the Netherlands, the figure was 7 percent for all employees, in Spain, 10 percent and in Portugal nearer 20 percent.

The age point at which the full minimum wage becomes payable varies from 18 in France, Spain and Greece to 20 in Portugal, 21 in Belgium and 23 in the Netherlands. In each case, young employees receive a graduated percentage of the full adult rate. In Denmark, West Germany and Italy, collective agreements generally provide for workers over the age of 18 to receive the full adult rate, but this is subject to the fulfilment of necessary training qualifications.

\section{Legal enforcement of collective agreements}

The nature of legal support for collective agreements is in its way just as important as statutory provisions laying down minimum terms and conditions which apply to all employees. Firstly this is because even in systems with a high degree of statutory intervention some matters are left up to sector-level collective bargaining, such as the minimum wage in West Germany. Secondly, in all systems legal intervention plays an important role in stabilising collective agreements, by requiring employers, in some circumstances, to recognise representative unions and to bargain with them, and to observe the terms of the agreements to which they are parties. Thirdly, the law may extend the effect of collective agreements beyond the immediate parties by imposing the minimum terms of sector-level agreements on under-organised employers and sectors (Wedderburn and Sciarra, 1988). 
Table 2: Minimum wages by law and collective agreement in the European Community, 1989

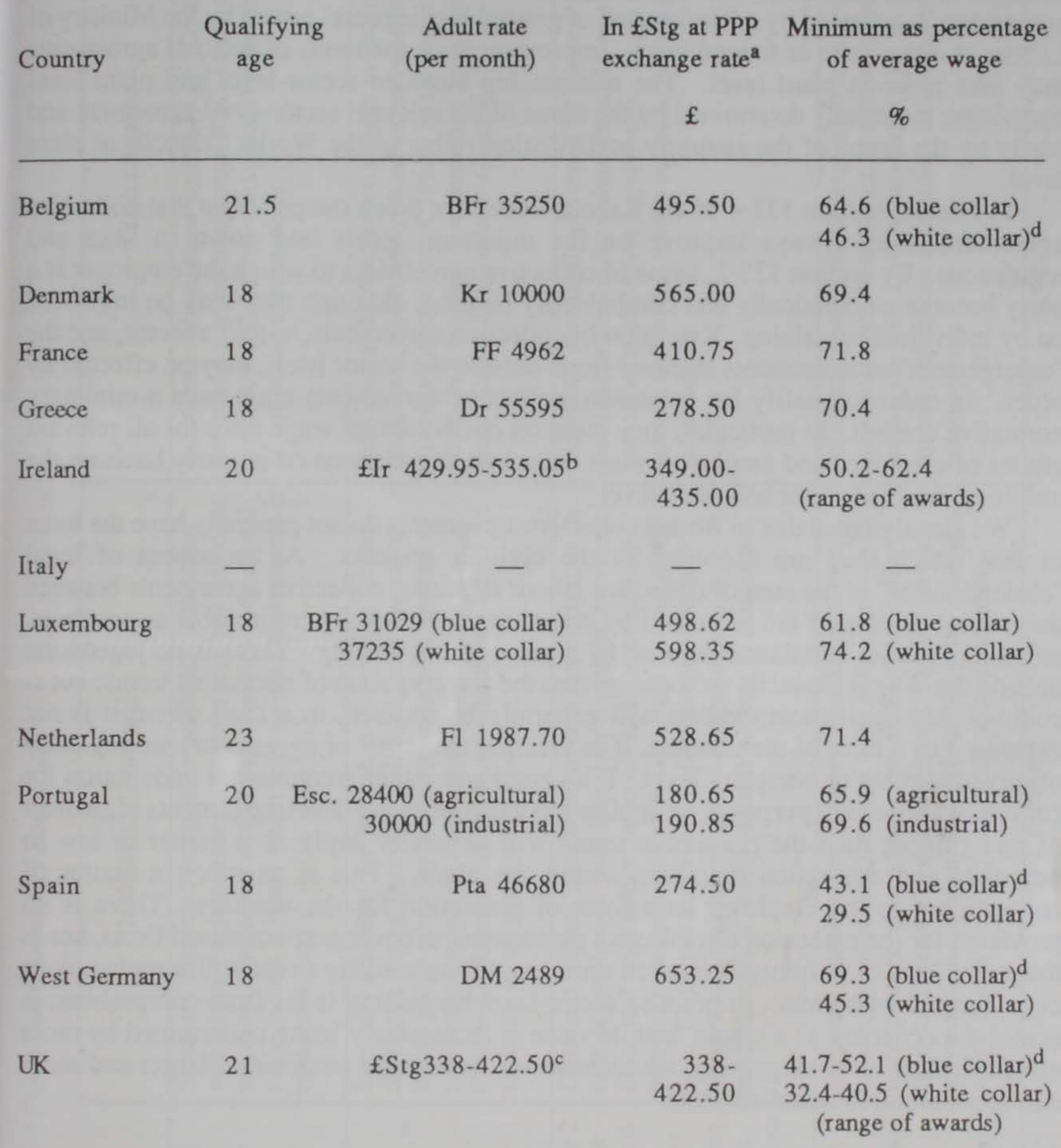

Source: Minford (1989).

Notes: a PPP: Purchasing power parity exchange rate, refers to exchange rate after adjusting for relative price levels. Calculated by Minford (1989).

b Refers to the range of awards made by Joint Labour Councils.

c Refers to the range of awards made by Wages Councils.

d Refers to the minimum wage expressed as a percentage of the average blue collar wage and white collar wage respectively.

In most of the continental European systems, specific legislation provides for the incorporation of terms from collective agreements into individual contracts of employment. In West Germany, the effect of the Collective Agreements Act 1949 (as amended in 1969) is broadly to give the normative terms of sector collective agreements 
the force of statutory regulation within the scope of their coverage, which may be national or regional within a particular industry. Thus terms and conditions are automatically and compulsorily implied into the contracts of employment of union members; in practice, although not as a matter of law, employers accord the same benefits to non-unionists working alongside union members. Extension of collective agreements is achieved by a "declaration of general bindingness" issued by the Ministry of Labour at either state or federal level. Improvement on the terms of sectoral agreements may take place at plant level. The relationship between sector-level and plant-level bargaining is partially determined by the terms of the relevant sector-level agreement and partly by the scope of the statutory participation rights of the Works Councils at plant level.

In France, section 132-4 of the Labour Code lays down the principle that collective agreements may always improve on the minimum terms laid down in laws and regulations. By section 135-2, terms of collective agreements to which the employer is a party become automatically and compulsorily binding, although they may be improved on by individual bargaining. Extension of collective agreements, within a sector, and the "enlargement" of agreements to cover firms outside the sector itself, may be effected by order. In order to qualify for extension, collective agreements must have a minimum normative content. In particular, they must set out minimum wage rates for all relevant grades of employee and employers must enter into negotiations on a yearly basis on the minimum wage at sector and plant level.

We already noted that in Britain collective agreements do not generally have the force of law which they are accorded in the civilian systems. As an aspect of legal "abstentionism" in the area of collective labour relations, collective agreements between unions and employers are presumed by statute not to be legally enforceable as contracts, unless the parties stipulate otherwise by a provision in writing. There is no legislation outside the Wages Councils sector to govern the incorporation of normative terms, but at common law such incorporation will generally be implied, in a case where it is not expressed as a term of the contract, if in practice the terms of agreements are regularly observed at plant or company level. If an employer either recognises a trade union for collective bargaining purposes, or applies the terms of sector-level agreements regardless of recognition, then the normative terms will generally apply as a matter of law to unionists and non-union members within the plant. This is as much a matter of convenience to the employer as a form of protection for the workers. There is no provision for the extension of collective agreements to cover non-unionised firms, nor is there any form of statutory obligation upon employers actually to recognise trade unions or to bargain with them. In practice sector-level bargaining is far from comprehensive across the economy as a whole, and its value is increasingly being undermined by more effective plant level bargaining, which however tends to be confined to larger and more strongly-unionised establishments.

\section{Security of employment}

Historically, the movement of regulation in the area of dismissal lay first of all in the imposition of minimum periods of notice, with greater protection for white collar and managerial employees, and in requiring special justification for summary dismissals (Vogel-Polsky, 1986). In the post war period, the requirement of "good cause" as a precondition of termination of employment has become generally observed. This process was given considerable impetus by ILO Recommendation 119 of 1963, although some countries had already adopted forms of dismissal regulation by that time. National systems generally distinguish between personal dismissals, on the one hand, and economic or collective dismissals, "redundancies", on the other. Most systems adopt 
Table 3: Dismissal laws in selected European Community countries

\begin{tabular}{|c|c|c|c|}
\hline Country & Notice periods & Individual dismissals & Redundancies \\
\hline France & $\begin{array}{l}1 \text { to } 2 \text { months depending } \\
\text { on length of service } \\
\text { ( } 6 \text { months minimum); } \\
\text { custom and practice } \\
\text { (less than } 6 \text { months) }\end{array}$ & $\begin{array}{l}\text { Summary dismissal for gross misconduct. Dismissal } \\
\text { with notice for just cause, with severance pay based on } \\
\text { seniority. Employee with } 2 \text { years' service may appeal } \\
\text { to the labour tribunal which may award reinstatement or } \\
\text { compensation for unfair dismissal. }\end{array}$ & $\begin{array}{l}\text { Individual redundancies permitted on economic grounds. } \\
\text { Severance pay based on seniority. Legal obligation } \\
\text { to consult and inform workplace representatives in case } \\
\text { of collective redundancies. }\end{array}$ \\
\hline Italy & $\begin{array}{l}\text { Determined by custom } \\
\text { and practice or } \\
\text { collective agreement. }\end{array}$ & $\begin{array}{l}\text { Summary dismissal for just cause. Employee (unless } \\
\text { dismissed during period of probation) may appeal to } \\
\text { labour judge who may order reinstatement, continued } \\
\text { payment of wages or compensation for unfair } \\
\text { dismissal. Automatic right to severance pay based on } \\
\text { seniority in all cases of dismissal. }\end{array}$ & $\begin{array}{l}\text { Individual redundancies are subject to general law of } \\
\text { dismissal. Collective redundancies regulated by national } \\
\text { collective agreement of } 1965 \text {. Employer may apply for } \\
\text { short-time working compensation from the Integration } \\
\text { Fund (Cassa Integrazione Gaudagni). }\end{array}$ \\
\hline $\begin{array}{l}\text { West } \\
\text { Germany }\end{array}$ & $\begin{array}{l}\text { Blue collar workers: from } 2 \\
\text { weeks to } 3 \text { months; white } \\
\text { collar workers: from } 1 \text { to } 6 \\
\text { months; in each case } \\
\text { depending on seniority. } \\
\text { Inferior protection for blue } \\
\text { collar workers declared un- } \\
\text { constitutional by the courts. }\end{array}$ & $\begin{array}{l}\text { Dismissal without notice for serious misconduct or in } \\
\text { case of employees with less than } 6 \text { months' service. } \\
\text { Dismissal with notice for misconduct, unsuitability, } \\
\text { breach of contract. No automatic right to severance } \\
\text { pay. Employee may claim unfair dismissal before } \\
\text { labour court which may award compensation, or } \\
\text { reinstatement if works council objects to dismissal. }\end{array}$ & $\begin{array}{l}\text { Individual dismissals governed by general law of dismissal. } \\
\text { No legal provision for redundancy pay as such but extensive } \\
\text { provision in collective agreements. Legal requirement to } \\
\text { consult and inform works councils in case of collective } \\
\text { redundancies. }\end{array}$ \\
\hline UK & $\begin{array}{l}\text { From } 1 \text { to } 12 \text { weeks } \\
\text { depending on length of } \\
\text { service (minimum } 4 \text { weeks). }\end{array}$ & $\begin{array}{l}\text { Summary dismissal for gross misconduct or serious } \\
\text { breach of contract. Dismissal with notice for } \\
\text { incompetence, misconduct, unsuitability or "other } \\
\text { substantial reason". Employee with } 2 \text { years' service } \\
\text { may claim unfair dismissal before industrial tribunal } \\
\text { which may award reinstatement or compensation. }\end{array}$ & $\begin{array}{l}\text { Individual redundancies permitted on economic grounds. } \\
\text { Individual right to redundancy compensation for } \\
\text { employees with } 2 \text { years' service. Legal requirement to } \\
\text { consult and inform recognised unions in case of collective } \\
\text { redundancies. }\end{array}$ \\
\hline
\end{tabular}


qualifying thresholds of some kind which limit the scope of protection to regular employees with a period of continuous service.

Minimum notice periods correlated to length of service are a general feature of the European systems. In West Germany they are based on legislation of 1926 which amended section 622 of the Civil Code. White collar workers are entitled to a minimum of 1 month or 6 weeks' notice in some cases, rising to 3 months with 5 years' service above the age of 25,4 months with 8 years, 5 months with 10 years and 6 months with 12 years. Blue collar workers receive a minimum of 2 weeks' notice, rising to 1 month after 5 years, 2 months after 10 years and 3 months after 20 . These service qualifications refer to years after the age of 35; in 1986 the Federal Constitutional Court declared this provision unconstitutional in so far as it differentiated blue collar from white collar workers. In France and Britain legislation makes no formal distinction between white collar and blue collar workers, and lays down notice periods ranging from a few weeks, in Britain, to between 2 and 3 months at most for workers with more than 2 years' service. Collective agreements and workplace customs provide for longer periods. In Italy there is no legislation governing notice periods as such which are governed by collective agreements and workplace custom.

The West German Dismissal Protection Acts of 1951 and 1969 require dismissal to be "socially justified" on the grounds of an individual's conduct or lack of capacity for the job. Similarly, in France the Labour Code permits dismissal with notice for reasons of just cause (cause réelle et sérieuse), which include incompetence and illness, and summary dismissal for faute lourde and faute grave, in which case the employee may also lose rights to severance pay and holiday pay. In Italy the notion of a "justified motive" dates from legislation of 1966.

An important element in each of these systems is the imposition of detailed procedural preconditions for dismissal, with the possibility of appeal to an independent labour court with the power in some instances to order the continuation of the contract of employment and the reinstatement of the employee. In Germany, the works council has the right to object to a dismissal, in which case the contract of employment remains in force until the matter is resolved by the labour court, unless the employer succeeds in getting an exemption order from the court. Employees who are not kept in employment may still be reinstated if the labour court finds that they were unjustly dismissed, although this happens only in a very small percentage of cases. The normal remedy would then be compensation, which consists of one month's salary for each year of service, and a higher rate for more senior employees. In France, a worker who has been unfairly dismissed may appeal to the labour tribunal which has the power to order reinstatement if the worker has more than 2 years' service, and is employed in a firm employing more than 10 workers. Reinstatement is also dependent on the agreement of both sides. Otherwise compensation representing up to 6 months' wages may be ordered. Employees may also be entitled to severance and holiday pay, either under the legislation or under the superior terms of collective agreements.

The most stringent procedure, at least in terms of direct legal control is that laid down in Article 18 of the Italian Workers Statute of 1970. Appeals are heard by the labour court judge sitting in the civil court. An unfair dismissal renders the termination of the contract "void", in which case the employer has the choice of either accepting reinstatement or continuing to pay the worker his contractual wages. In practice, not all cases of dismissal will come under the 1970 Act, which is limited to firms of a certain size, and there are also difficulties of interpreting this provision in the light of earlier legislation, not formally repealed, which laid down the remedy of compensation up to a maximum of 12 months as the alternative to reinstatement.

Unfair dismissal legislation was introduced in Britain in 1971. Although employers are required to show that the reason for the dismissal is potentially fair within the categories laid down in the legislation, in practice this is not difficult and much of the emphasis in the case law lies on the fairness or otherwise of the employer's procedure. 
Complaints of unfair dismissal are made before an industrial tribunal. Reinstatement is the principal remedy at the tribunal's disposal, but there is no provision for the contract of employment to be kept in force during litigation and, once again, very few successful cases result in the re-employment of the worker. Compensation awards are restricted by a low limit to the maximum weekly pay which is used to compute the claimant's damages and by a statutory limit on the overall size of the award.

Controls over redundancies form the other significant aspect of European dismissal laws. A degree of harmonisation in the area of collective redundancies and the transfer of employees on the sale or insolvency of a business has been brought about by the 3 European Directives, concerning redundancy consultation (1975), employee rights in company transfers (1977) and employer insolvency (1980). As far as redundancy is concerned, the emphasis is on requiring employers to notify the employees affected and the state authorities in advance of their intentions. The managerial power to dismiss for an economically valid reason is not, as such, restricted, but in varying degrees the need to demonstrate a good operational reason and to conform to procedural requirements serve to stabilise the employment relationship and make redundancy a last resort. In West Germany, works councils have the right to be consulted about proposed redundancies and to object to the criteria laid down for the selection of redundant employees, while in France redundancies required the authorisation of the labour inspectorate until 1986. There remains a requirement to inform and consult the enterprise committee. In Britain there is a duty to consult with the relevant "recognised union". This is increasingly recognised to be an ineffective requirement in a system which imposes no form of a duty to recognise or to bargain. In Italy collective redundancies are regulated by a national collective agreement dating from 1965.

In addition to laws governing termination of employment, laws providing for income security also play a significant part in stabilising the employment relationship. This category includes laws providing for the regular payment of wages and prohibiting unauthorised deductions; maintaining the continuity of the contract of employment during sickness and pregnancy, and/or providing for the payment of sick pay and maternity pay; providing for the payment of wages during lay-off ("guaranteed pay" in Britain, compensation for "partial unemployment" in some of the continental systems); and prohibiting unjustified changes in working conditions. In each case, state legislation is viewed as laying down minimum conditions which are frequently the subject of improvement through collective bargaining.

The Italian system of compensation for partial unemployment is a particularly striking example of the use of income support legislation to stabilise the employment relationship. Payments from the integration fund, the Cassa Integrazione Guadagni (CIG), were used during the 1980 s to fund long periods of unemployment for industrial workers, primarily in large industrial enterprises. In this way, and coupled with the strict legal controls over dismissal, the CIG has effectively operated as a replacement for unemployment compensation which preserves the link between the firm and the worker. This style of regulation can be contrasted with the use of redundancy compensation in Britain in the 1980s to encourage firms to sever ties with their surplus labour force, a process which contributed to the very high levels of registered unemployment at the start of the 1980s.

\section{Anti-discrimination legislation and the protection of specific groups}

Additional protection from dismissal for trade union members and officials is an important mechanism for supporting the collective bargaining process at plant level. In Italy, the labour court will order the reinstatement of a dismissed official at a preliminary hearing unless the employer produces sufficient reasons for the dismissal. In West 
Germany, this type of protection is applied to members and prospective members of works councils.

Specific protection is also provided within dismissal law for pregnant workers. Italian law, for example, prohibits the dismissal of women workers during pregnancy and for the child's first year unless there is serious misconduct, or the closure of the business in which the worker is employed. In West Germany, there are restrictions on dismissal during pregnancy and the period of maternity leave. In Britain, there is a wider power to dismiss a pregnant worker, but this is coupled with a duty to re-employ and to pay maternity pay for a certain period. A number of complex procedural requirements must however be observed by the employee and various exceptions for small firms and firms unable to re-integrate the employee after maternity leave have been introduced, leaving this area of the law in a particularly unsatisfactory state.

The more general provisions of anti-discrimination law imply not just the establishment of a minimum "floor" for collective bargaining but also the re-structuring of collective agreements and other payment systems where they are a source of institutional or "indirect" discrimination against women workers and racial minorities. This trend may be observed in Britain, where the introduction firstly of the Equal Pay Act in 1970 and subsequently of the principle of equal pay for work of equal value in 1983 prompted the revision of the more obvious forms of direct and indirect discrimination in payment structures.

The separate treatment of women in protective legislation, which dates from the nineteenth century, has become increasingly anachronistic with the passage of general equality legislation. Moves to repeal restrictions on women's nightworking have taken place in a number of countries, partly in response to the efforts of the European Commission to achieve the implementation in member states of the 1976 Directive on Equal Treatment in Employment. The situation of young workers is more complex, and here most systems retain restrictions on night work and shift work by workers under the age of 18 or 21 as the case may be. The principal exception is Britain, where the Employment Act 1989 removed all restrictions on the employment and working hours of young people between the ages of 18 and the school leaving age of 16 (Deakin, 1990).

\section{Derogations from labour standards: a route to labour market flexibility?}

The aim of the statutory floor of rights is to set a basic standard from which there can be no derogation or exception, either through collective bargaining or through individual agreement. Wages and employment conditions below a certain level are "taken out of competition", a process which has potentially beneficial implications for industrial efficiency as well as for the control of poverty and for the general application of principles of equity within the wage system (Deakin and Wilkinson, 1989). At the same time, as we have seen, the purpose of statutory intervention is to provide a platform for collective bargaining, so that the basic terms and conditions laid down by law can be improved by joint regulation. "Collective" labour laws, which include legislation for the recognition of trade unions for collective bargaining purposes, the imposition of a duty to bargain, the application and extension of collective agreements, and the preservation of a right to strike, are all accordingly found to some degree within each of the European systems.

Historically, there has always been a tension between these 2 forms of regulation, with the need to entrench minimum standards through law being combined with a recognition of the value of union autonomy. The result is diversity in the relative importance of individual employment law and collective bargaining in terms of the establishment of basic labour market rights. In Denmark, for example, where a strong 
and highly centralised trade union movement has been able to establish general labour standards through various levels of collective bargaining, there is relatively little scope for direct floor of rights legislation. Similarly, in West Germany there is little demand for a statutory minimum wage as such and the introduction of such a measure might be seen as an infringement of the unions' role in collective bargaining and national and regional industry levels. Countries with a tradition of a strong centralised state and a high level of state intervention in the economy, such as France and Spain in their very different ways, illustrate a more extensive role for floor of rights legislation as well as providing widespread legal support for collective bargaining (Erbes-Seguin, 1989). Britain is an example of a system in which basic terms and conditions were left almost entirely to voluntary collective bargaining to achieve, with only limited state intervention to tackle low pay in under-organised parts of the labour market and a relatively weak and incomplete form of job security legislation.

The demands of labour market flexibility constitute a different, and historically more recent, form of pressure upon the notion of the statutory floor of rights. From this perspective, the imposition by law of general standards for the contract of employment is a source of rigidity and inefficiency in the operation of the labour market, and if not an initial cause of the high unemployment of the early 1980s then at least a possible barrier to its removal. This point of view has led to calls for greater exceptions or derogations to be allowed to employment protection legislation, so increasing the scope again for individual bargaining or at least for a greater degree of decentralisation in decision-making over the terms and conditions of employment. This trend, broadly speaking, takes 2 forms (Mückenberger and Deakin, 1989): firstly, greater legal acceptance and/or encouragement of "atypical" or "non-standard" forms of employment relationship, that is, part time, fixed-term and temporary employment contracts which may in varying degrees provide employers with greater flexibility in the use of labour and provide exemption from employment protection costs; and secondly, legal authorisation for contractual derogations from employment protection even in the case of the "core" of permanent employees, sometimes through individual bargaining (increasingly the case in Britain), sometimes through decentralised collective bargaining at plant or enterprise level (as is the case in France, Italy and Germany).

Atypical work poses a problem for traditional forms of labour law and social security which are based to a high degree around the model of the "standard employment relationship" of long-term, continuous and regular employment with a single employer. Not only is there a tendency for labour law rights to be restricted to workers who fall within the legal category of the dependent "employee" or wage-earner and who meet certain minimum requirements of length and continuity of service; rights accrue with seniority and sometimes according to status within the hierarchy of the firm. The result is that even otherwise regular employees with discontinuous work records and broken career patterns suffer from discrimination. The problem of exclusion increasingly affects workers in "precarious" or casual jobs whose employment status is unclear and whose contractual relations with employers are irregular. This group includes homeworkers, the fake self-employed in sectors such as construction and services, part time workers holding multiple jobs and on-call workers and others who do not have a regular working week. Apart from this segment of highly insecure workers, other part time, temporary and fixedterm contract workers may enjoy a high level of employment stability with a single employer and high job satisfaction. In their case, however, both wider employment opportunities and long-term income security are adversely affected by the lack of a "permanent" job (Büchtemann and Quack, 1989).

Most Western European governments in the 1980s have seen atypical work as a potential means of reducing unemployment, and to that extent have actively sought to promote more flexible working arrangements. In some countries this has been brought about through a tightening of qualifying conditions, as in Britain where the service qualification for most statutory employment rights was gradually extended from 6 months 
to 2 years and where part time workers are excluded from labour law protection if they work for less than 16 hours per week (or less than 8 hours if they have 5 years continuous service with their employer) (Deakin and Wilkinson, 1989). As an exception to the usual rule by which statutory employment rights take priority over contrary terms in the individual contract of employment, fixed-term employees may agree to waive their rights to claim unfair dismissal and redundancy compensation upon the expiry of their contracts. In return the employer must offer the employee a fixed-term of at least 1 year (prior to 1982 he had to offer a term of 2 years).

The emphasis, in Britain, on freedom of contract at the hiring stage meant that no formal change in the legislative structure was needed to authorise the growth of atypical work relationships; by contrast, in most of the continental systems a much greater emphasis was placed, historically, on the value of the standard employment relationship, with the result that new legislation was needed if employers were to be permitted to hire labour on a part time or temporary basis (Kravaritou-Manitakis, 1988). Thus laws to extend the role of fixed-term and part time hirings were passed in West Germany (1985), France (1982, 1984 and 1986), Belgium (1981), Italy (1978, 1983 and 1984), Portugal (1984) and Spain (1984). In many cases these "deregulatory" laws were coupled with requirements for parity of treatment in terms of wages and conditions of employment between atypical and permanent employees, a requirement which stands in stark contrast to the inferior protection accorded to temporary and part time workers in Britain, and for regulation by company level agreements of the terms on which atypical workers are hired. The principal example of this type of regulation is the West German Employment Promotion Act of 1985 (Daübler and Le Friant, 1986).

However, the legal situation is complicated in many cases by the continued application of qualifying thresholds and seniority criteria which have the effect, in practice, of undermining the principle of parity, particularly as regards non-wage payments. Nor does the principle of parity extend, in most instances, to equality within the social security system, where high qualifying thresholds and continuity of work requirements continue to be strictly applied (Kravaritou-Manitakis, 1988).

A further means of encouraging more flexible forms of work has been for national governments to provide direct and indirect subsidies, through the taxation system, to employers taking on unemployed workers on a part time or fixed-term contract basis (Rodgers and Rodgers, 1989). In Britain subsidies have been paid directly to employers taking on the young unemployed for training and work experience in a variety of schemes. An additional technique has been to pay the adult unemployed a small weekly supplement on top of their benefit in return for attending work experience and training courses.

Subsidies for the employment of young people on fixed-term contracts also operate in France, Italy, Spain, Portugal and Belgium. In most cases these operate through rebates on social security contributions. In France and Italy the state has encouraged job creation by offering subsidies for the formation of "solidarity contracts" between employers and unions at plant or company level, whereby state subsidies are made available in return for agreement on reductions in working time and the employment of unemployed workers usually on a fixed-term contract basis (Wedderburn and Sciarra, 1988). In Spain, the legislation of 1984 created no fewer than 15 types of temporary work contract covering separate justifications for the departure from a permanent job offer, and involving varying levels of state subsidy through the social security system. The result has been a substantial increase in the proportion of fixed-term contract workers to between a quarter and a third of all employees, with an estimated 90-95 percent of new hirings in the private sector taking the form of a temporary contract (Recio, 1990). 
Table 4: Part time and temporary employment in the European Community, 1983-1988

\begin{tabular}{|c|c|c|c|c|}
\hline \multirow{3}{*}{ Country } & \multicolumn{2}{|c|}{ Part time ${ }^{a}$} & \multicolumn{2}{|c|}{ Temporaryb } \\
\hline & 1983 & 1988 & 1983 & 1988 \\
\hline & $\%$ & $\%$ & $\%$ & $\%$ \\
\hline Belgium & 8.3 & 11.0 & 4.1 & 5.4 \\
\hline Denmark & 25.6 & 25.5 & $\begin{array}{c}12.7 \\
(1985)\end{array}$ & 11.1 \\
\hline France & 8.9 & 12.0 & 3.2 & 7.8 \\
\hline Greece & 4.9 & 4.0 & - & 17.6 \\
\hline Ireland & 5.8 & 8.2 & 3.1 & 9.1 \\
\hline Italy & 3.5 & 5.0 & 4.9 & 5.8 \\
\hline Luxembourg & 6.2 & 6.7 & 1.8 & 3.7 \\
\hline Netherlands & 20.9 & 29.4 & 3.8 & 8.7 \\
\hline Portugal & - & 4.5 & - & 18.5 \\
\hline Spain & - & 4.7 & - & 22.3 \\
\hline West Germany & 12.0 & 12.7 & $\begin{array}{c}11.1 \\
(1984)\end{array}$ & 11.2 \\
\hline UK & 19.4 & 22.8 & 3.1 & 5.9 \\
\hline Community & - & 13.6 & - & 9.6 \\
\hline
\end{tabular}

Source: European Commission (1990).

Notes: a Part time employees as a proportion of all employees.

b Temporary employees as a proportion of all employees.

The extent and composition of atypical working varies greatly from one country to another (European Commission, 1990). As Table 4 shows, levels of part time working are highest in the Netherlands (which approaches 30 percent of the employed population), Denmark and the UK (each between 20 and 25 percent). Sweden also has a high proportion of part time workers, around 25 percent of the employed labour force. Part time work appears to be relatively insignificant, on the other hand, in Spain, Portugal, Italy and Greece. Temporary employment, however, is high in Spain (over 20 percent), Portugal and Greece (each between 15 and 20 percent). Most striking, however, is the rate of growth of atypical work in the 1980s: part time work increased by 28 percent but 
full-time employment by only 2.4 percent in the 10 member states of the EEC between 1983 and 1988.4

As we have already seen, these figures cannot be equated in any sense with numbers of workers excluded from labour law protection. Most part time workers with hours above the statutory thresholds will enjoy protection at least formally equivalent to that of full timers. Nevertheless, the growth not just of atypical work as a whole but of a large segment of part time and temporary workers who are excluded from basic labour law and social security protection, and of groups for whom a lower level of job security and employment opportunities apply, is a matter of concern. It should also be borne in mind that the groups tending to fill atypical jobs are those most vulnerable to labour market discrimination - married women returning to the labour market after looking after families, young workers entering the market for the first time and the displaced adult male unemployed who are trying to find a new "permanent" job (Rodgers, 1989).

Attempts to achieve greater labour market flexibility through changes in the law are not confined to the issue of atypical work. Increasingly, national governments have attempted to introduce a greater number of derogations from labour and employment protection standards, and to encourage the decentralisation of collective bargaining from sector to company or establishment level, so giving employers more extensive freedom to vary working patterns and wage payment systems.

In Britain, the Wages Act 1986 removed young workers, below the age of 21, altogether from the scope of statutory wages orders, and restricted the powers of the remaining Wages Councils to setting a single hourly minimum rate and overtime rate for their sectors. Previously they had set minimum rates for all grades of workers in the manner of sector level collective agreements. The British government's programme of privatising and contracting-out public sector services has also led to a de facto reduction in the scope of coverage of collective agreements, as subcontractors have withdrawn recognition from previously established unions and undercut sector level agreements which, in the absence of extension legislation, cannot be made to apply on a general basis. Even within areas of strong trade union organisation, the effectiveness of sectorlevel agreements as a form of labour market regulation has been steadily reduced. This is partly due to changes in trade union legislation which make the organisation of industrial action on a sectoral basis and the exercise of economic pressure at labour-market level both potentially unlawful.

With the downgrading in Britain of collective bargaining and employment protection standards, there is a trend towards the "individualisation" of terms and conditions of employment. In some sectors where contracting-out has become common, what is sometimes called individualisation is simply another way of describing the consequences of the de-recognition of unions and the disapplication of collective agreements. As far as directly-employed, "core" workers are concerned, legislation has encouraged the growth of personal pay incentives by providing tax subsidies for firms operating systems of profitrelated pay and employee share ownership plans. So far these measures have had a limited impact, however. The range of payment systems in both manufacturing and service sectors is highly diverse and forms of performance-related pay have been used for many years. The relative lack of detailed legal regulation of wages and payment systems has meant that British employers have long enjoyed a high level of flexibility in this regard.

Significant changes to working time legislation, aimed at introducing greater flexibility in working schedules, have taken place in France, Italy and Belgium, but in each case a role for collective bargaining as a mechanism for controlling and monitoring derogations from labour standards has been preserved. In France, for example, the establishment of the 39 hour week in 1982 was made conditional upon implementation by agreement at plant and company level, through which provision could be made for

4 This calculation excludes Spain and Portugal who joined the Community from 1986. 
increased working of 2 or 3 hours a week as long as a 39 hour average was maintained over an 8 or 12 week period, and further legislation in 1987 envisages company level agreement on flexible annual working hours, Sunday working and women's nightwork (Erbes-Seguin, 1989). Similar reforms have also been proposed for West Germany (Mückenberger and Deakin, 1989). A Bill presented to the Federal Parliament would allow working hours to increase from 8 to 10 hours per day as long as the 8 hour average was maintained over a 4 month period, with provision for further derogations to be authorised by collective bargaining. Liberalisation of restrictions on Sunday working and on the working week of women employees are also part of the proposal.

Belgian legislation of 1983 allowed companies to derogate from a range of legal controls on the working day and week and restraints on weekend working, on condition that the new arrangements met with the approval of the trade unions, through the collective bargaining process, and of the Ministry of Labour. A further condition was that the new arrangements had to involve the hiring of extra employees. Following the legislation, a number of flexibility agreements were drawn up, involving increased weekend and variable shift working. In 1986 a national collective agreement made further provision for the introduction of flexible working time arrangements, and in 1987 the main provisions of this agreement were incorporated into legislation. It is now possible for company-based agreements to move towards totally flexible annual hours as long as the 39 hour weekly average is maintained on a yearly basis.

These developments suggest that collective bargaining at company or plant level will increasingly be used as a means of achieving flexibility in the application of labour standards, a process which maintains an active role both for the floor of rights and for joint regulation (Wedderburn and Sciarra, 1988). This technique may be contrasted with the tendency in Britain for both statutory rights and collective bargaining to be downgraded, resulting in a reduced coverage of general labour standards and an increasing trend towards individualisation and insecurity for employees in the non-unionised workforce (Deakin and Wilkinson, 1989).

\section{Conclusion}

At a time of deregulation and growing international competition and economic integration within Europe, the future for the floor of rights is uncertain. In some areas there has been an erosion of minimum legal standards governing terms and conditions of employment, as governments have sought to encourage greater flexibility in the use and deployment of labour by firms. However, with the exception of Britain, the demand for greater flexibility in the application of standards has not led to a wholesale dismantling of the floor of rights. In most systems collective bargaining continues to play a significant, and in some ways an increasingly important, role in regulating terms and conditions of employment. This role for collective bargaining derives from the importance of plant and company level agreements in achieving greater flexibility of working time and contractual arrangements, within a more general framework of security set by minimum legal standards and a continuing commitment of governments to the principle of joint regulation in industry.

The continuing emphasis on a viable role for collective bargaining and employment protection in the continental systems is partly a product of the much closer relationship which existed, historically, between the forms of collective bargaining and the law regulating the contract of employment. Rather than seeking a return to the individual contract of employment, legislative reform in the 1980s has sought to re-define the relationship between collective labour law and the individual contract of employment through the techniques of controlled derogations which were examined above. In Britain, on the other hand, the long tradition of legal voluntarism which gave priority to 
collective bargaining over direct legal regulation meant that only a weak and partial floor of rights could develop. Deregulation in Britain has seen both a withdrawal of employment protection for "marginal" groups and widespread state intervention in industrial relations procedures aimed at limiting the social and economic power of the trade unions. What we observe, therefore, is not a withdrawal of the state to leave a "freed-up" labour market, but rather a range of legal responses in different countries, which in many areas have modified and indeed extended the role of the state in labour market regulation.

Much of the justification for deregulation in the areas of atypical work and working time flexibility is the need to re-integrate the unemployed into the labour market. However, the flexibility debate has tended up to now to address only one side of the problem, namely employers' needs for a more flexible legal framework for the adjustment of labour costs and inputs. Less attention has been paid to the use of the law to promote flexibility on the supply side of the labour market, by providing active incentives for individuals to adopt a greater variety of working patterns and by encouraging disadvantaged groups to enter or re-enter the labour market. Indeed, the aims of greater supply side flexibility are likely to be frustrated by a policy of wholesale deregulation. There is a growing recognition that deregulation itself can be a source of undesirable "rigidities" on both the demand and supply sides of the labour market (Streeck, 1988).

It is doubtful, for example, whether the removal of employment protection rights from existing job holders will have a beneficial impact on unemployment, or increase the employment opportunities of workers who currently have access only to atypical jobs. The more likely outcome, at least on the basis of the experience in Britain up to now, is a growing casualisation of work and a downgrading of job quality, together with increased discrimination against vulnerable labour market groups (Deakin and Wilkinson, 1989). Cuts in social and employment protection of the kind which have taken place in Britain over the past decade make worker mobility and external flexibility less and not more likely as they have a disproportionate impact upon the income security of the unemployed, the low paid and others who do not have regular access to stable employment. From this point of view, a high level of social protection in labour law and social security may have beneficial effects in terms of labour market participation rates and the re-integration of the unemployed into the labour force (Deakin and Wilkinson, 1989).

The growth of atypical employment in the 1980 s poses a number of problems for the traditional forms of the floor of rights. Policies promoting atypical work may result in increasing division and segmentation of the labour market as a whole. There is a need for labour law and social security to accommodate a greater variety of contractual forms of employment and to ensure that the atypical forms do not just become dead-end or expendable jobs. The alternative is a growing dualism within the labour market, between existing job-holders on the one hand and new entrants (young workers, migrant workers) and those attempting to re-enter after a period out of regular waged employment (married women and displaced workers) on the other, who are pushed into insecure and short-term jobs or jobs with no regular career structure. It is not clear that any lasting progress has been made if, in an attempt to narrow the gap between the unemployed and those in regular work, a dualist labour law policy creates new barriers to mobility between those in atypical work, on the one hand, and those with a "standard" employment relationship on the other. Unless governments take positive measures to improve the protection offered to atypical workers and to provide more effective rights at the level of the labour market, so-called flexible working arrangements will continue to be more a matter of necessity rather than choice for vulnerable labour market groups and something to be avoided for "core" workers.

There is therefore a role for new forms of labour and social security law which can provide a framework of security beyond the immediate employment relationship, so encouraging greater mobility within the labour market and providing substance to the idea 
of individuals' rights to a "choice of occupation". Laws promoting the integration of atypical workers into existing systems of protection and establishing principles of equal treatment between groups in the labour market are an example of this form of "reregulation". It will be necessary to pay greater attention than before to the role of antidiscrimination legislation and social security law as forms of labour market rights, and to their relationship to the floor of rights within the contract of employment (Mückenberger and Deakin, 1989).

There does not seem to be any immediate prospect of the introduction of fully effective harmonisation of social and labour laws at EC level (Mosley, 1990). Nevertheless, there is acceptance of the role to be played by a basic floor of rights in imposing a "level playing field" in the single market (European Commission, 1990). It remains to be seen whether the debate about a "social area" within an integrated European economy has sufficiently revitalised the development of social and labour standards for viable alternatives to deregulation to be advanced and implemented.

\section{References}

Blanpain, R. (ed) (1988) Legal and contractual limitations on working time in the European Community. European Foundation for the Improvement of Living and Working Conditions. Luxembourg.

Büchtemann and Quack (1989). 'Bridges' or 'traps'? Non-standard employment in the Federal Republic of Germany. In G. and J. Rodgers, (ed) (1989) Precarious jobs in labour market regulation. The growth of atypical employment in Western Europe. Geneva. International Institute for Labour Studies.

Däubler, W. and Le Friant, M. (1986) Un récent exemple de flexibilisation législative: la loi allemande pour la promotion de l'emploi du 26 Avril 1985. Droit social. SeptembreOctobre: $715-720$.

Deakin, S. (1990) Equality under a market order: the Employment Act 1989. Industrial law journal. 19: 1-19.

Deakin, S. and Wilkinson, F. (1989) Labour law, social security and economic inequality. London, Institute of Employment Rights.

Eberlie, R. (1990) The new health and safety legislation of the European Community. Industrial law journal. 19: 65-80.

Erbes-Seguin, S. (1989) Flexibility and the relationship between the individual employment contract and collective labour law. International journal of the sociology of law. 17: 307-326.

European Commission (1990) Explanatory memorandum on the proposals for directives concerning certain employment relationships. Brussels.

European industrial relations review (1986) Minimum pay in 12 countries: part 1, adults. 144: $22-26$.

European industrial relations review (1987) West Germany: collective bargaining in 1986. 160: 13-14. 
Hepple, B. (1987) The crisis in EEC labour law. Industrial law journal. 16: 77-87.

Kravaritou-Manitakis, Y. (1988) New forms of work. Labour law and social security aspects in the European Community. European Foundation for the Improvement of Living and Working Conditions. Luxembourg.

Minford, M. (1989) Minimum wages in Europe: is Britain out of line? Low pay review. 37: 20-36.

Mosley, H. (1990) The social dimension of European integration. International labour review. 129(2): 147-163.

Mückenberger, U. and Deakin, S. (1989) From deregulation to a European floor of rights: labour law, flexibilisation and the European single market. Zeitschrift für ausländisches und internationales Arbeits-und Sozialrecht. 3: 157-206.

Recio, A. (1990) The quality of new jobs in Spain (1985-1989): structural changes and labour policies. Presented at the 12 th annual conference of the International Working Party on Labour Market Segmentation

Rodgers, G. and Rodgers, J. (ed) (1989) Precarious jobs in labour market regulation. The growth of atypical employment in Western Europe. Geneva. International Institute for Labour Studies.

Rubery, J., Deakin, S. and Horrell, S. (1990) Change and continuity in working time patterns in Britain. In G. Bosch, et al. (ed) Working time in thirteen industrialised countries. Geneva. International Institute for Labour Studies (forthcoming).

Streeck, W. (1988) Comment on "Rigidities in the labour market". Government and opposition. 23: 413-23.

Trade Union Congress (1989) Review of working time in Britain and Western Europe. London.

Vogel-Polsky, E. (1986.) The problem of unemployment. In B. Hepple (ed) The making of labour law in Europe. London, Mansell.

Vogel-Polsky, E. (1990) What future is there for a social Europe following the Strasbourg summit? Industrial law journal. 19: 65-80.

Wedderburn, Lord (1986) The worker and the law. Harmondsworth, Penguin.

Wedderburn, Lord (1990) The Social Charter, European company and employment rights. An outline agenda. London, Institute of Employment Rights.

Wedderburn, Lord, and Sciarra, S. (1988) Collective bargaining as agreement and as law; neo-contractualist and neo-corporative tendencies of our age. In A. Pizzorusso (ed) Law in the making. Berlin, Springer-Verlag.

Wyatt, D. (1989) Enforcing EEC social rights in the United Kingdom. Industrial law journal. 18: 197-216. 